\title{
The Relationship between Pain Beliefs and Psychiatric Symptoms of Patients with Fibromyalgia Syndrome
}

\author{
Fibromyalji Sendromu Hastalarının Ağrı İnançları ile Psikiyatrik Belirtileri Arasındaki İlişki
}

\author{
ArZu YÜKSEL ${ }^{1}$ \\ (D) 0000-0001-7819-2020 \\ Hatice TAMBAĞ $\breve{2}^{2}$ \\ (D) 0000-0002-0812-2489 \\ Ahmet KARAKOYUN ${ }^{3}$ \\ (D) 0000-0001-8288-9744
}

\begin{abstract}
Aim: This study was conducted to examine the relationship between the pain beliefs and psychiatric symptoms of the patients with fibromyalgia syndrome (FMS).

Material and Methods: This cross-sectional study was conducted with 145 patients diagnosed with FMS between August 2018 and January 2019 in the Physical Therapy and Rehabilitation polyclinic of Aksaray University Training and Research Hospital. The sociodemographic data form prepared by authors, Pain Beliefs Scale (PBS), Depression Anxiety Stress Scale (DASS) and Visual Analogue Scale (VAS) were applied to the patients.

Results: Mean age of FMS patients is $35.42 \pm 9.10$ years, $57.9 \%(\mathrm{n}=84)$ are female, $70.3 \%$ $(n=102)$ are married and $95.9 \%(n=139)$ live in nuclear families. Of the patients, $46.9 \%(n=68)$ were reported that they perceived the pain at the severity of 9-10 (mean: 8.12 \pm 1.29 ) according to VAS. Mean score of organic beliefs was $4.87 \pm 0.77$, and mean score of psychological beliefs was $5.17 \pm 0.52$. It was found that depression $(62.8 \%)$ and anxiety $(33.1 \%)$ levels were very advanced, and stress (45.5\%) levels were advanced. A statistically significant positive correlation was detected between the DASS total and the subscales of depression, anxiety and stress and both organic beliefs and psychological beliefs (all $p$ values $<0.001$ ).

Conclusion: The patients' pain beliefs and pain perception levels were found high and the rate of accompanying psychiatric symptoms was also high. While the patients' pain beliefs increase, their depression, anxiety and stress levels also increase. It is important to use holistic approaches to strengthen the response given to treatment in patients with FMS.
\end{abstract}

${ }^{1}$ Aksaray University Faculty of Health Sciences Department of Nursing, Aksaray, Turkey

${ }^{2}$ Mustafa Kemal University Faculty of Health Sciences Department of Nursing, Hatay, Turkey

${ }^{3}$ Aksaray University Medical Faculty Department of Physical Medicine and Rehabilitation, Aksaray, Turkey

\section{Sorumlu Yazar \\ Corresponding Author Arzu YÜKSEL \\ arzuyukse176@gmail.com}

Geliş Tarihi / Received : 03.11.2019 Kabul Tarihi / Accepted : 21.12.2019 Çevrimiçi Yayın Tarihi / Available Online
Keywords: Fibromyalgia syndrome; pain beliefs; psychiatric symptoms.

ÖZ

Amaç: $\mathrm{Bu}$ çalışma fibromiyalji sendromlu (FMS) hastaların ağrı inançları ile psikiyatrik belirtileri arasındaki ilişkiyi incelemek amacıyla yapılmıştır.

Gereç ve Yöntemler: Kesitsel türdeki bu çalışma, Aksaray Üniversitesi Eğitim ve Araştırma Hastanesinin Fizik Tedavi ve Rehabilitasyon polikliniğinde Ağustos 2018 ve Ocak 2019 tarihleri arasında FMS tanısı almış olan 145 hasta ile yapılmıștır. Hastalara yazarlar tarafindan hazırlanmış olan sosyodemografik veri formu, Ağrı İnançları Ölçeği (AİÖ), Depresyon Anksiyete Stres Ölçeği (DASÖ) ve Vizüel Analog Skala (VAS) uygulanmıştır.

Bulgular: FMS hastalarının yaş ortalamaları 35,42 $\pm 9,10$ yıl olup \%57,9'u ( $\mathrm{n}=84)$ kadın, \%70,3'ü (n=102) evli ve \%95,9’u (n=139) çekirdek ailede yaşamaktadır. Hastaların \%46,9'u $(\mathrm{n}=68)$ VAS'a göre ağrıyı 9-10 (ortalama: $8,12 \pm 1,29)$ şiddetinde algıladığını bildirmiştir. Organik inançlar puan ortalaması $4,87 \pm 0,77$ ve psikolojik inançlar puan ortalaması ise $5,17 \pm 0,52$ 'dir. Depresyon $(\% 62,8)$ ve anksiyete $(\% 33,1)$ düzeylerinin çok ileri düzeyde olduğu, stres $(\% 45,5)$ düzeylerinin ise ileri düzeyde olduğu bulunmuştur. DASÖ toplam ve alt ölçeklerden, depresyon, anksiyete ve stres ile hem organik inançlar hem de psikolojik inançlar arasında istatistiksel olarak anlamlı pozitif korelasyon saptanmıştır (tüm p değerleri <0,001). Sonuç: Hastalarının ağrı inançları ve ağrı algılama düzeylerinin yüksek olduğu, aynı zamanda eşlik eden psikiyatrik belirti oranının da yüksek olduğu tespit edilmiştir. Hastaların ağrı inançları artarken depresyon, anksiyete ve stres düzeyleri de artmaktadır. FMS hastalarında tedaviye verilen yanıtı güçlendirebilmek için bütüncül yaklaşımların kullanılması önemlidir. Anahtar kelimeler: Fibromiyalji sendromu; ağrı inançları; psikiyatrik belirtiler. 


\section{INTRODUCTION}

Fibromyalgia syndrome (FMS) is a chronic and complexed syndrome with non-musculoskeletal clinical symptoms such as sleep disorder, tiredness, weakness, headache and depression together with prevalent musculoskeletal pains in the body, its etiology is still not known exactly $(1,2)$. While FMS can be observed in all the ethnic groups, in every age and gender, it is seen more frequently between the ages of 40 and 60 and in female patients (3). Its prevalence is between $2-8 \%$. In a research conducted in Turkey, the FMS prevalence was found 3-6\% (4). It is reported that FMS decreases the functionality of the individuals in the physical, psychological and social terms, and it has a negative effect on cognitive performance, personal relations (including sexuality and parenting), activities of work and daily living (5). In patients with FMS, pain is one of the most important symptoms influencing the quality of life in a negative way (6).

Pain experience and severity is a phenomenon which shows individual differences and is difficult to diagnose $(7,8)$. Pain perception is influenced by many emotional, behavioral and cognitive factors such as gender, education and culture. Moreover, the severity and frequency of the pain and coping ability are affected by personal traits and beliefs of the individual $(9,10)$. According to the cognitive view, pain beliefs are considered as the keystone of the individual's thought system.

Pain beliefs also affect the severity of the pain perception and coping abilities $(11,12)$. Pain has organic and psychological dimensions. Organic pain belief means to believe in having physical injuries or threatened wellbeing, that is, pain will be as high as the severity of the damage and injury. In the psychological pain belief, psychological factors such as depression and anxiety are believed to be the cause of pain $(13,14)$.

Even though pain is the major symptom of FMS, conditions like depression, anxiety, stress and sleep disorders affect the quality of life in patients. Depressive disorders are the most frequently observed psychiatric comorbidity in FMS, and its prevalence varies between 20 $80 \%$ (15). Besides, it is also stated that the chronic pain observed in FMS may lead to depression or anxiety by affecting especially the social life in a negative way (6).

In a study conducted abroad, lifelong affective disorder rate of FMS patients was discovered as $71 \%$ (16). In a study conducted with FMS patients in Turkey, depression symptoms were found by $54.8 \%$, and in another study in Turkey, $37.3 \%$ of the patients were diagnosed with major depression. In the study, depression in FMS was demonstrated to be linked with pain and disease severity (17). However, no relationship was detected between pain severity and depression, and between depression severity and FMS severity in FMS patients, but there are studies indicating a relationship with anxiety (18). In this study, it was aimed to contribute to the etiology of the disease by investigating the relationship between pain beliefs and psychiatric symptoms of FMS patients.

\section{MATERIALS AND METHODS}

This cross-sectional study was conducted with 145 patients diagnosed with FMS between August 2018 and January 2019 in the Physical Therapy and Rehabilitation polyclinic of Aksaray University Training and Research
Hospital. Patients who were under 18 years of age, had mental problems or communication difficulties, and disagreed to participate in the study, were excluded.

Before the study, written permission was obtained from the Head Physician of Aksaray University Training and Research Hospital and Aksaray Provincial Directorate of Health. Ethics committee approval of the study was received from Aksaray University Human Researches Ethics Committee (dated 29.06.2018 and numbered 144). The patients who participated were informed about the study, and the data were collected after explaining that personal information would remain confidential.

\section{Data Collection Tools}

For the collection of the data, the Sociodemographic Data Form prepared by authors, Visual Analogue Scale (VAS), Pain Beliefs Scale (PBS) and Depression Anxiety Stress Scale (DASS) were used.

Sociodemographic Data Form: It consists of questions prepared by researchers in line with the literature $(1,3,6,10,14-18)$, and the questions include the ages, educational statuses, professions, economic conditions, family structures and pain perceptions of the patients.

Pain Beliefs Scale (PBS): It was developed by Edwards et al. (19) in 1992 in order to evaluate the beliefs related to the cause and treatment of pain. It was adapted to Turkish following the validity and reliability study conducted by Berk HÖS (20) in 2006. Consisting of 12 items in total, the scale has two test areas as organic beliefs (8 items) and psychological beliefs (4 items). The organic belief test shows that pain is mostly of organic origin and the psychological belief test shows that pain experience is under the influence of psychological factors (21). Scores are in the 6-point Likert type varying between 1 (never) and 6 (always) for each item. For each subtest, the total score is calculated by summing the scores obtained from the items in that subtest and dividing it into the number of the items of that subtest. There is no cut point for the scale scores, the increase in the score obtained from the subscore of the scale points out that the pain beliefs of that test are high, and the decrease in the score indicates that the pain beliefs of that test are low. The highest score that can be obtained from the subdimensions of organic and psychological beliefs is 6 , and the lowest score is $1(19,21)$. In the reliability study of the scale, the Cronbach alpha coefficient for internal consistency scores were found as 0.71 for the organic beliefs subtest and 0.73 for the psychological beliefs subtest (20). In this study, it was obtained as 0.85 for the organic beliefs subtest and 0.35 for the psychological beliefs subtest.

Depression Anxiety Stress Scale (DASS): The scale developed by Lovibond and Lovibond (22) in 1995 consists of 42 items in total as depression (14 items), anxiety (14 items) and stress (14 items). The depression items measure the individuals' discontentment, desperation, insignificance, loss of interest and low energy levels. The anxiety items assess the individual's autonomic arousal, situational anxiety, subjective anxiety, and muscle response levels. The stress items measure the levels of the symptoms of relaxation difficulty, nerve stimulation, easy distress and boredom, discomfort, overreaction and intolerance. High scores obtained from each of the depression, anxiety and stress dimensions show that the individual has that problem. The total scores of the scale 
vary between 0 and 42 for each subdimension. The DASS is a 4-point Likert type scale, and the items are scored between 0 and 3 (22). The DASS was adapted to Turkish by Akın and Çetin (23) in 2007. The internal consistency coefficients Cronbach alpha were found as follows 0.89 for the whole scale, 0.90 for depression, 0.92 for anxiety and 0.92 for stress. In this study, they were found as follows, 0.98 for the whole scale, 0.97 for depression, 0.92 for anxiety and 0.95 for stress.

\section{Statistical Analysis}

SPSS v.24 package program was used for evaluation of the data. Descriptive statistics such as frequency, percentage, mean \pm standard deviation, median and minimummaximum were used. Whether the data had a normal distribution was assessed with Kolmogorov-Smirnov test. Because the data did not have a normal distribution, Spearman correlation analysis was used for determination of the relationship between the variables. The level of $\mathrm{p}<0.05$ was considered statistically significant.

\section{RESULTS}

Of the 145 FMS patients included in the study $57.9 \%$ $(n=84)$ were female, $37.9 \%(n=55)$ were aged between 31 and 40 (mean age $35.42 \pm 9.10$ years), $70.3 \%(n=102)$ were married and $95.9 \% \quad(n=139)$ were living in nuclear families. Of the patients $37.9 \%(n=55)$ were high school graduates, $53.8 \%(n=78)$ did not work, $89.7 \%(n=130)$ had a moderate economic status and $62.8 \%(\mathrm{n}=91)$ were retired (Table 1).

Table 1. Sociodemographic characteristics of patients

\begin{tabular}{lc}
\hline Characteristics & $\mathbf{n}(\boldsymbol{\%})$ \\
\hline Age, mean \pm SD & $35.42 \pm 9.10$ \\
Age & \\
$19-30$ years & $52(35.9)$ \\
$31-40$ years & $55(37.9)$ \\
$41-68$ years & $38(26.2)$ \\
Gender & \\
Female & $84(57.9)$ \\
Male & $61(42.1)$ \\
Marital Status & \\
Married & $102(70.3)$ \\
Single & $43(29.7)$ \\
Education & \\
Primary school & $48(33.1)$ \\
Secondary school & $14(9.7)$ \\
High school & $55(37.9)$ \\
University and above & $28(19.3)$ \\
Employment & \\
Working & $67(46.2)$ \\
Not working & $78(53.8)$ \\
Economic Status & \\
Good & $10(6.9)$ \\
Moderate & $130(89.7)$ \\
Bad & $5(3.4)$ \\
Family Structure & \\
Nuclear & $139(95.9)$ \\
Large & $6(4.1)$ \\
Social Security & \\
Retirement fund & \\
Artisans and self-employed & $31(21.4)$ \\
Retired & $17(11.7)$ \\
Green Card & $91(62.8)$ \\
SD: Standard Deviation & $6(4.1)$ \\
\hline
\end{tabular}

When pain characteristics are reviewed, most of the FMS patients $(56.6 \%, n=82)$ reported that they had pain for a while between 1 and 6 months, 31.0\% $(n=141)$ stated that their pain was in their back-waist area, and $46.9 \%(n=68)$ perceived pain at the severity of 9-10 according to the VAS. Plus, $87.6 \%(\mathrm{n}=127)$ do not use any psychiatric drugs (Table 2).

The patients' PBS mean score of organic beliefs subdimension is $4.87 \pm 0.77$, and their mean score of psychological beliefs subdimension is $5.17 \pm 0.52$. The mean DASS total score was $66.24 \pm 29.04$, and in the subdimensions, the mean score of depression was found as $28.51 \pm 12.40$, anxiety as $14.01 \pm 8.14$ and stress as $23.72 \pm 9.53$ (Table 3).

When the anxiety and stress levels of the patients were reviewed, it was discovered that depression (62.8\%) and anxiety $(33.1 \%)$ levels were very advanced and stress $(45.5 \%)$ levels were advanced (Table 4$)$.

A positively strong correlation was detected between the DASS total score $(\mathrm{r}=0.800)$ and the subdimensions of depression $(\mathrm{r}=0.821)$, anxiety $(\mathrm{r}=0.752)$, stress $(\mathrm{r}=0.773)$ and organic beliefs, and a positively moderate and significant relationship was found between the DASS total score $(\mathrm{r}=0.496)$ and the subdimensions of depression $(\mathrm{r}=0.518)$, anxiety $(\mathrm{r}=0.498)$, stress $(\mathrm{r}=0.473)$ and psychological beliefs (All p values <0.001, Table 5).

Table 2. Characteristics related to patients' pain

\begin{tabular}{lc}
\hline Characteristics & $\mathbf{n}(\boldsymbol{\%})$ \\
\hline VAS, mean \pm SD & $8.12 \pm 1.29$ \\
VAS & \\
$\quad$ Perception at the severity of 5-6 & $20(13.8)$ \\
Perception at the severity of 7-8 & $57(39.3)$ \\
Perception at the severity of 9-10 & $68(46.9)$ \\
Pain Duration & \\
1-6 months & $82(56.6)$ \\
7-12 months & $32(22.0)$ \\
$\geq 13$ months & $31(21.4)$ \\
Psychiatric Medicine & $18(12.4)$ \\
Using & $127(87.6)$ \\
Not using & \\
Pain Location, (n=455)* & $135(29.7)$ \\
Head-neck & $141(31.0)$ \\
Back-waist & $88(19.3)$ \\
Arm-shoulder & $78(17.1)$ \\
Leg-knee & $13(2.9)$ \\
$\quad$ Other & SD: Standard Deviation, VAS: Visual Analogue Scale, *: More than one \\
option were allowed and percentages were calculated over 455 response.
\end{tabular}

Table 3. PBS and DASS scores

\begin{tabular}{lcc}
\hline Scale & Mean \pm SD & Median (Min-Max) \\
\hline PBS & & \\
$\quad$ Organic Beliefs & $4.87 \pm 0.77$ & $5.00(3-6)$ \\
$\quad$ Psychological Beliefs & $5.17 \pm 0.52$ & $5.25(3-6)$ \\
DASS & & \\
$\quad$ Depression & $28.51 \pm 12.40$ & $34.00(1-42)$ \\
$\quad$ Anxiety & $14.01 \pm 8.14$ & $15.00(0-31)$ \\
$\quad$ Stress & $23.72 \pm 9.53$ & $27.00(4-36)$ \\
$\quad$ Total DASS & $66.24 \pm 29.04$ & $76.00(6-103)$ \\
\hline
\end{tabular}

SD: Standard Deviation, Min: Minimum, Max: Maximum, PBS: Pain Beliefs Scale, DASS: Depression Anxiety Stress Scale 
Table 4. Depression, anxiety and stress levels of patients

\begin{tabular}{lccc}
\hline & Depression & Anxiety & Stress \\
\hline Normal & $14(9.7)$ & $36(24.9)$ & $32(22.1)$ \\
Slight & $11(7.5)$ & $7(4.7)$ & $11(7.6)$ \\
Moderate & $16(11.0)$ & $25(17.2)$ & $21(14.5)$ \\
Advanced & $13(9.0)$ & $29(20.1)$ & $66(45.5)$ \\
Very advanced & $91(62.8)$ & $48(33.1)$ & $15(10.3)$ \\
\hline
\end{tabular}

Table 5. Correlation between patients' pain beliefs and depression anxiety stress scale scores

\begin{tabular}{lcccc}
\hline & \multicolumn{2}{c}{ Organic Beliefs } & \multicolumn{2}{c}{ Psychological Beliefs } \\
& r & p & r & p \\
\hline Depression & 0.821 & $<0.001$ & 0.518 & $<0.001$ \\
Anxiety & 0.752 & $<0.001$ & 0.498 & $<0.001$ \\
Stress & 0.773 & $<0.001$ & 0.473 & $<0.001$ \\
Total DASS & 0.800 & $<0.001$ & 0.496 & $<0.001$ \\
\hline
\end{tabular}

DASS: Depression Anxiety Stress Scale

\section{DISCUSSION}

Pain severity of the patients who participated in the study was evaluated by VAS and the mean value was obtained as 8.12 . In a study conducted by Türkyılmaz et al. (24) in 2011, the VAS mean value in fibromyalgia patients was reported as 7.9. In various studies, VAS values were detected similarly (25-27). It is seen that this value in our study complies with the results of other studies.

When the pain beliefs of the patients in our study were assessed, the mean score of the organic beliefs subdimension was found as $4.87 \pm 0.77$, and the mean score of the psychological beliefs subdimension was obtained as $5.17 \pm 0.52$. Considering that the score to be received from the scale is at least one and maximum six, both organic and psychological pain beliefs of the patients are high. In a study conducted with patients with chronic pain, the mean score of organic beliefs of 86 patients was discovered as $2.83 \pm 0.99$ and the mean score of psychological beliefs was found as $2.39 \pm 1.47$ (28). In a study conducted with the elderly people living in a nursing home, the quality of life, pain levels and pain beliefs of the elderly people were examined, and the mean score of organic beliefs was detected as $3.02 \pm 0.74$, the mean score of psychological beliefs was discovered as $1.80 \pm 0.73$ (29). In our study, we can say that both organic and psychological belief levels of the patients with FMS are quite high.

In our study, the depression, anxiety and stress levels of the patients were found at an advanced level. It is known that a significant part of the FMS patients has depression, and in some studies, it has been reported that there is a relationship between depressive symptoms and pain severity $(30,31)$. As a result of the study conducted by Vespa et al. (32) in 2015, through the comparison of 57 FMS patients and 203 healthy individuals, the depression levels of the healthy individuals were found to be low and moderate, however, the depression levels of FMS patients were at a high level. In various studies, FMS patients were reported to have depressive symptoms $(6,15)$. In a study examining the quality of life and psychiatric symptoms of fibromyalgia patients, anxiety was observed in $67.4 \%$ of the patients and depressive symptoms in $87.2 \%$ (33). In a study researching psychiatric symptoms, $50 \%$ of 191 FMS patients reported high anxiety and depression. Tiredness and sleep disorder were found to be correlated with high depression (34). We can say that psychiatric symptoms such as depression and anxiety are more common in FMS patients than healthy individuals, and the presence of depression and anxiety increases pain severity, affecting the quality of life in a negative way.

In our study, a relationship was detected between the DASS total score and the subdimensions of depression, anxiety, stress and organic (positively strong) and psychological (positively moderate) beliefs. While the pain beliefs of the patients increase, their depression, anxiety and stress levels also increase. When the results of the studies on different populations were reviewed in the literature, it was reported in a study that the risk of FMS patients increased in terms of depressive symptoms, and they tended to be more unhappy and feel discontent (34). In another study, a statistically significant relationship was discovered between pain and psychological well-being and organic pain belief and psychological well-being (28). We can say that this finding in our study is parallel with the results of the studies in the literature.

\section{CONCLUSION}

In our study, the FMS patients' pain beliefs and pain perception levels were found high, and the rate of accompanying psychiatric symptoms was also high. While the pain beliefs of the patients increase, their depression, anxiety and stress levels also increase. Considering that FMS is not a physiological disease or mental disorder alone and it is a cluster of symptoms consisting of the combination of the symptoms in this area, it is believed that treatment interventions with a holistic approach is important before the disease becomes chronic.

\section{REFERENCES}

1. Wolfe F, Walitt B, Perrot S, Rasker JJ, Häuser W. Fibromyalgia diagnosis and biased assessment: sex, prevalence and bias. PLoS One. 2018;13(9):e0203755.

2. Wolfe F, Clauw DJ, Fitzcharles MA, Goldenberg DL, Katz RS, Mease P, et al. The American College of Rheumatology preliminary diagnostic criteria for fibromyalgia and measurement of symptom severity. Arthritis Care Res (Hoboken). 2010;62(5):600-10.

3. Kösehasanoğulları M, Yılmaz N. Fibromyalgia syndrome and neuropathic pain. Aegean J Med Sci. 2018;1(1):26-31.

4. Topbaş M, Çakırbay H, Güleç H, Akgol E, Ak I, Can G. The prevalence of fibromyalgia in women aged 2064 in Turkey. Scand J Rheumatol. 2005;34(2):140-4.

5. Galvez-Sánchez CM, Duschek S, Reyes Del Paso GA. Psychological impact of fibromyalgia: current perspectives. Psychol Res Behav Manag. 2019;12:11727.

6. Ataoğlu S, Özçetin A, Ataoğlu A, İçmeli C, Makarç S, Yağlı M. The relationship between pain intensity, anxiety and depression in patients with fibromyalgia and rheumatoid arthritis. Anadolu Psikiyatri Derg. 2002;3(4):223-6.

7. Edwards CL, Fillingim RB, Keefe F. Race, ethnicity and pain. Pain. 2001;94(2):133-7. 
8. Eti Aslan F, Badır A. Reality about pain control: The knowledge and beliefs of nurses on the nature, assessment and management of pain. Agri. 2005;17(2):44-51.

9. Richards J, Hubbert AO. Experiences of expert nurses in caring for patients with postoperative pain. Pain Manag Nurs. 2007;8(1):17-24.

10. Koçoğlu D, Özdemir L. The relation between pain and pain beliefs and sociodemographic-economic characteristics in an adult population. Agri. 2011;23(2):64-70.

11. Babadağ B, Alparslan GB, Güleç S. The relationship between pain beliefs and coping with pain of algology patients'. Pain Manag Nurs. 2015;16(6):910-9.

12. Sloan TJ, Gupta R, Zhang W, Walsh DA. Beliefs about the causes and consequences of pain in patients with chronic inflammatory or noninflammatory low back pain and in pain-free individuals. Spine (Phila $\mathrm{Pa}$ 1976). 2008;33(9):966-72.

13. Berk HÖS, Bahadır G. The experience of chronic pain and pain beliefs. Agri. 2007;19(4):5-15.

14. Pons T, Shipton E, Mulder R. The relationship between beliefs about pain and functioning with rheumatologic conditions. Rehabil Res Pract. 2012;2012:206263.

15. Aguglia A, Salvi V, Maina G, Rossetto I, Aguglia E. Fibromyalgia syndrome and depressive symptoms: comorbidity and clinical correlates. J Affect Disord. 2011;128(3):262-6.

16. Hudson JI, Hudson MS, Pliner LF, Goldenberg DL, Pope HG Jr. Fibromyalgia and major affective disorder: a controlled phenomenology and family history study. Am J Psychiatry. 1985;142(4):441-6.

17. Altunören Ö, Orhan FÖ, Nacitarhan V, Özer A, Karaaslan MF, Altunören O. Evaluation of depression, temperament and character profiles in female patients with fibromyalgia syndrome. Arch Neuropsychiatry. 2011;48(1):31-8.

18. Evren B, Evren C, Yapıcı A, Güler MH. Severity of pain and relationship with psychiatric symptoms in patients with fibromyalgia. Anadolu Psikiyatri Derg. 2005;6(2):69-74.

19. Edwards LC, Pearce SA, Turner-Stokes L, Jones A. The pain beliefs questionnaire: an investigation of beliefs in the causes and consequences of pain. Pain. 1992;51(3):267-72.

20. Berk HÖS. The experience of chronic pain and pain beliefs: the Turkish validation study of the pain beliefs questionnaire [PhD Thesis]. İstanbul: İstanbul University Institute of Social Sciences; 2006.

21. Walsh DA, Radcliffe JC. Pain beliefs and perceived physical disability of patients with chronic low back pain. Pain. 2002;97(1-2):23-31.
22. Lovibond PF, Lovibond SH. The structure of negative emotional states: Comparison of the depression anxiety stress scales (DASS) with the beck depression and anxiety inventories. Behav Res Ther. 1995;33(3):335-43.

23. Akın A, Çetin B. The depression anxiety and stress scale (DASS): the study of validity and reliability. Educational Sciences: Theory \& Practice. 2007;7(1):241-68.

24. Türkyılmaz AK, Kurt EE, Karkucak M, Çapkın E. Sociodemographic characteristics, clinical signs and quality of life in patients with fibromyalgia. Eurasian J Med. 2012;44(2):88-93.

25. Kara M, Reşorlu H, Döner D, Güçlü O, Dereköy FS. Evaluation of the relationship between voice disorders and the disease activity in patients with fibromyalgia syndrome. KBB Forum. 2016;15(2):49-55.

26. Karadağ A, Canbaş M, Parlak M. The effect of balneotherapy on pain and quality of life in patients with fibromyalgia. Mustafa Kemal Üniv Tip Derg. 2018;9(35):114-20.

27. Özcan DS, Aras M, Köseoğlu BF, Güven ŞŞ. Quality of life and associated conditions in women with fibromyalgia syndrome. Turk J Osteoporos. 2013;19(2):42-7.

28. Yıldızeli Topçu S. Relations among pain, pain beliefs, and psychological well-being in patients with chronic pain. Pain Manag Nurs. 2018;19(6):637-44.

29. Dogan N, Goris S. The effect of pain levels and pain beliefs of elderly people living in nursing home on quality of life. Int J Caring Sci. 2018;11(2):947-54.

30. Chang MH, Hsu JW, Huang KL, Su TP, Bai YM, Li $\mathrm{CT}$, et al. Bidirectional association between depression and fibromyalgia syndrome: a nationwide longitudinal study. J Pain. 2015;16(9):895-902.

31. Soriano-Maldonado A, Amris K, Ortega FB, SeguraJiménez V, Estévez-López F, Álvarez-Gallardo IC, et al. Association of different levels of depressive symptoms with symptomatology, overall disease severity, and quality of life in women with fibromyalgia. Qual Life Res. 2015;24(12):2951-7.

32. Vespa A, Meloni C, Giulietti MV, Ottaviani M, Spatuzzi R, Merico F, et al. Evaluation of depression in women affected by fibromyalgia syndrome. J Depress Anxiety. 2015;4(2):178.

33. Zhang Y, Liang D, Jiang R, Ji X, Wang Y, Zhu J, et al. Clinical, psychological features and quality of life of fibromyalgia patients: a cross-sectional study of Chinese sample. Clin Rheumatol. 2018;37(2):527-37.

34. Gormsen L, Rosenberg R, Bach FW, Jensen TS. Depression, anxiety, health-related quality of life and pain in patients with chronic fibromyalgia and neuropathic pain. Eur J Pain. 2010;14(2):127.e1-8. 